Paideusis

\title{
A Response to "Advantage New Brunswick: A Province Reaches to Fulfill Its Destiny", a Report by the Commission on Post-Secondary Education in New Brunswick
}

Emery J. Hyslop-Margison

Volume 16, Number 3, 2007

URI: https://id.erudit.org/iderudit/1072495ar

DOI: https://doi.org/10.7202/1072495ar

See table of contents

Publisher(s)

Canadian Philosophy of Education Society

ISSN

0838-4517 (print)

1916-0348 (digital)

Explore this journal

Cite this document

Hyslop-Margison, E. (2007). A Response to "Advantage New Brunswick: A Province Reaches to Fulfill Its Destiny", a Report by the Commission on Post-Secondary Education in New Brunswick. Paideusis, 16(3), 101-104. https://doi.org/10.7202/1072495ar 


\title{
A Response to Advantage New Brunswick: A Province Reaches to Fulfill Its Destiny, a Report by the Commission on Post-Secondary Education in New Brunswick
}

\author{
EMERY J. HYSLOP-MARGISON \\ University of New Brunswick, Canada
}

\begin{abstract}
These are especially dangerous times for democracies and for the institutions designed to protect the fundamental principles and practices on which they are based. At the forefront of our democratic institutions are administratively independent and intellectually free universities whose primary mission is the unencumbered and sometimes politically controversial pursuit of knowledge and truth. Thomas Jefferson, a great American champion of universities described their democratic importance in the following terms:
\end{abstract}

What object of our lives can we propose so important [as establishing a university]? What interest of our own which ought not to be postponed to this? Health, time, labor -- on what in the single life which nature has given us, can these be better bestowed than on this immortal boon to our country? The exertions and the mortifications are temporary; the benefit eternal. ${ }^{1}$

Many individuals within our neo-liberal society no longer consider questioning the assumptions of social organization a necessary condition or requirement of democratic citizenship. For these individuals, a group largely comprised of industry captains, government officials and economic policy makers, all of the important decisions about society have been made and are irreversible. The only remaining role for the rest of us, whether we are pipefitters, plumbers, students or academics is to respond, passively of course, to the technical and labour market demands of industry.

In our neo-liberal era, all authentic democratic learning, or education that encourages meaningful and engaged political participation of citizens in public policy discussions and development, is under constant siege as the labour market and its corporate directors now define what counts as "quality" education. Advantage New Brunswick represents yet another example of this anti-democratic perspective since it proposes dismantling significant portions of our provincial university system, institutions designed to keep questions about contemporary social and economic organization at the forefront of political debates.

The democratic role of the university includes providing space and opportunity for the critique of public policy decisions and the corresponding ideological agendas that drive them. Within a social and political milieu where the university's mission in this area is undermined, democracy is threatened because public debate and the scope of accepted circulating ideas are narrowed to predetermined

\footnotetext{
${ }^{1}$ Quote from "New Coin Celebrates Link Between Jefferson, University of Virginia" at http://www.virginia.edu/uvatoday/newsRelease.php?id=2643, retrieved November 12, 2007.
}

(C) Copyright 2007. The author, Emery J. Hyslop-Margison, assigns to Paideusis the right of first publication and educational and non-profit institutions a non-exclusive license to use this document for personal use and in courses of instruction provided that the article is used in full and this copyright statement is reproduced. Any other usage is probibited without the express permission of the author. 
assumptions and objectives that comply with a monolithic point of view. Success, as defined by Advantage New Brunswick, is consistent with the neoliberal vision of education: a human capital enterprise designed to meet corporate and labour market needs.

The proposed dismantling of the University of New Brunswick in Saint John and its transformation into a polytechnic is most notably rationalized by the report on the basis of meeting short term corporate needs:

Saint John's emerging focus as an energy centre means that the polytechnic would be a natural extension of joint programming that would offer an enormous strategic advantage to the region and energy sectors. This would include technical, technological, and degree programs all related to energy, and offered not only in a single institution, but in an integrated fashion that facilitated synergy in research, teaching and learning.

(Miner \& L'Ecuyer, 2007, p. 20)

Aside from legitimately questioning the rationality of fossil fuel exploitation at a time when our planet stands in grave peril because of $\mathrm{CO}_{2}$ emissions, democratic learning, consistent with a university education, is usurped by training objectives to satisfy the needs of local industry. As a result, Saint John, one of the most populated metropolitan areas in New Brunswick, is left without any university, while Fredericton, with less than half as many citizens retains two such institutions. Obviously, the recommendation to dismantle UNBSJ clearly makes no demographic sense. But this is not an issue that ought to pit university against university because, as the document makes abundantly clear, all universities as independent and democratic institutions are under considerable threat. Instead, the point here is that certain private sector interests in Saint John are clearly directing provincial education policy in the region. The corporate domination of society establishes the market, in this case the influential Irving group of companies, as the sole patron of educational reform.

Within a neo-liberal context, the trend toward corporate responsiveness in education is highly ideological. By ensuring that the goals of the market become the goals of education, students are simultaneously indoctrinated into a monolithic world view. Successful ideologies typically seek to make their assumptions natural and self-evident by embedding them into "common sense" thinking. Under the guise that higher education in a global economy must be restructured to meet the needs of industry, then, universities, as complicit corporate allies, are actually limiting alternative social visions based on more humanistic assumptions about what constitutes a quality education and an acceptable society.

Suffice to say that "accountability," a common catchword these days for everyone outside of politicians and corporate leaders, is a prevailing theme throughout Advantage New Brunswick. We are told "the post-secondary system must be held to rigorous account" so that "students and employers can be confident that what institutions say they are doing is actually done and so that the quality of the outcomes is of the highest order." Consistent with the report's paternalistic approach, decision-making power in determining these outcomes would lie beyond the bounds of institutional democracy. The authors of the report suggest that, "decision-making authority would rest firmly in the hands of an appointed board and [the university] president."

Such a narrow view of university governance represents an ominous threat to the democratic principles of academic freedom and collegial governance on which our traditional university administrative model is founded. To quote the Canadian Association of University Teachers (CAUT): "Academic freedom requires that academic staff play a major role in the governance of the institution. Academic freedom means that academic staff must play the predominant role in determining curriculum, assessment standards, and other academic matters." The commission's report, if accepted, would therefore significantly undermine the role of faculty in university governance at a time when more and more matters of academic governance already fall under the jurisdiction of the university's managerial class. 
There is one final issue to address in response to Advantage New Brunswick. In its analysis, CAUT suggests the report gives a false impression that post-secondary education programs, tied to the labour market, will function as a means to address systemic unemployment and income disparity in New Brunswick. Indeed, the track record of linking education to labour market prognostications is historically a notoriously poor one, but even if we accept the report's rhetoric about a so-called knowledge economy, what are the actual labour market projections? Well, we know that WalMart, the master of big box retail outlets, is now the number one employer in the U.S. Further, a 1997 Industry Canada report established by the Prime Minister's Advisory Council on Science and Technology found no evidence of a skill shortage among Canadians and a recent version of Job Futures published by Human Resources Development Canada predicts that Canadian employment growth will remain in the comparatively low-skilled service sector for the foreseeable future. The domestic situation mimics that in the U.S. where the Bureau of Labor Statistics indicates the vast majority of job creation remains in low skilled and poorly paid retail and cashier occupations. Is this a "knowledge economy?"

The report's claim that its proposed educational reforms will enhance the province's international competitiveness fails to recognize that success or failure in the global economy is primarily determined by cheap sources of labour and inadequate environmental regulations rather than the education level of available workers. The proposed restructuring of higher education in New Brunswick may produce a subdued and ideologically compliant workforce, but it will have virtually no impact on alleviating the contemporary labour market difficulties confronted by workers, or economic disparity in the province.

The following, then, is a summary of the report's most serious implications:

- The idea of a university as a fundamental institution designed to promote and protect democratic ideals is replaced by a human capital model with educational priorities and agendas increasingly shaped by private sector and corporate labour market requirements.

- The academic freedom of all university faculty members is challenged by a proposed governance model based on external accountability and administrative fiat that reduces the role of faculty to token representation.

- Citizens of one of New Brunswick's largest metropolitan areas will be denied the opportunity to send their children to a local university. For some students, certainly those that come from economically disadvantaged backgrounds, this undoubtedly means denying them access to a university education entirely.

- Polytechnics and universities are expected to pursue practical objectives that satisfy enhanced labour market needs in the so-called knowledge based economy. However, present and foreseeable employment growth in the labour market is primarily in the low paying service and retail sectors.

In sum, then, what are we to extrapolate from this comprehensive challenge to post-secondary education in New Brunswick? The authors of the report suggest that, "There is no escaping the world we now live in," a claim only contingently true in cases where participatory democratic decision-making is removed from the realm of public policy formation. As Jefferson understood so well, universities are institutions of primary importance within democratic societies. The proposed range of educational reforms offered in the commission's report undermines both the democratic principles and structures of higher education in New Brunswick.

The marketplace and competition exalted in Advantage New Brunswick inevitably create a world of winners and losers where success is entirely measured by corporate or personal profit. Is this the definition of "success" and the educational legacy we wish to leave to the children of New Brunswick? Unlike the suggestions within the report, we have not reached the end of history. Through personal and collective activism directed toward protecting the most important democratic institutions in our society, 
our universities, we can influence educational reform. As Martin Luther King observed, "The arc of the moral universe is long, but it bends towards justice." The real educational advantage for New Brunswick and its citizens, then, requires establishing our province as the global prototype for genuine democratic learning rather than as an instrumental training ground to satisfy short term and environmentally dubious corporate economic interests. We are not witnessing a paradigmatic shift, but simply another, more advanced phase of the neo-liberal attack on education as a fundamental requirement of democratic societies. In the absence of counter-hegemonic forces, a dominant propaganda strategy has emerged, embraced in part by UNB's high level administration that presents market economy principles, practices and requirements as the inevitable framework for social and educational reconstruction.

\section{References}

Miner, Rick, \& L'Ecuyer, J. (2007). Advantage New Brunswick: A province reaches to fulfill its destiny. A report by the Commission on Post-Secondary Education in New Brunswick. Retrieved on November 1, 2007, from www.gnb.ca/cnb/promos/cpse/CEPNB_Report-e.pdf

\section{About the Author}

Emery Hyslop-Margison is Associate Professor and Canada Research Chair nominee at the Faculty of Education, University of New Brunswick, Fredericton, N.B. He can be reached at ehyslopm@unb.ca 